\section{Streifenförmige Ablagerung des Reaktionsprodukts bei einer Gasphasenreaktion}

\author{
Peter Bützer*
}

Abstract. The gas-phase reaction of $\mathrm{NH}_{3}$ with $\mathrm{HCl}$ in a glas tube (length $150 \mathrm{~cm}$, diameter $1-6 \mathrm{~cm}$ ) leads to solid depositions of $\mathrm{NH}_{4} \mathrm{Cl}$ on the glaswall, with a regular pattern of stripes. The peculiar structure is also observed with other volatile reactants leading to a salt as the only solid product. Variations of tubediameters and temperatures indicate a broad validity of the observations.

\section{Einleitung}

Die Bildung von regelmässigen Strukturen aus diffusen Zuständen ist im Zusammenhang mit der Chaos-Theorie (z.B. [1]) und der Synergetik [2] zu einer neuen Gruppe von Phänomenen geworden. Besonderheiten sind z.B. Spuren von Translationsflächen an gezogenen Einkristallstäben, welche eine Bandbildung zeigen [3]. Relativ selten sind gut erkennbare Muster bei chemischen Reaktionen wie bei den oszillierenden Reaktionen [4][5], bei strukturierten Fällungen [6][7] oder fraktalen Bildern bei Elektrolysen [8].

Das Prinzip der Abhängigkeit der Diffusionsgeschwindigkeit von der Molmasse, kann mit einem einfachen Experiment demonstriert werden [9][10]. Bei der Durchführung dieses gut bekannten Demonstrationsexperimentes zum Thema Gasdiffusion, wurde im Sinne von 'Serendipity' [11] die Bildung regelmässiger Ablagerungsmuster des Reaktionsprodukts gefunden.

\section{Experimente}

\subsection{Basisexperiment}

In ein waagrechtes Glasrohr von ca. $150 \mathrm{~cm}$ Länge und $1-6 \mathrm{~cm}$ Durchmesser, wurden gleichzeitig von der einen Seite ein Porzellanschiffchen mit etwa $2 \mathrm{ml} \mathrm{konz}$. $\mathrm{NH}_{3}$ - Lsg. $(25 \%)$, und von der anderen Seite ein Porzellanschiffchen mit $2 \mathrm{ml} \mathrm{konz.} \mathrm{HCl}(34 \%)$, etwa $5 \mathrm{~cm}$ eingeschoben. Die Öffnungen wurden sofort mit Gummistopfen verschlossen. Der Abstand der beiden Quellen war $123 \mathrm{~cm}$. $\mathrm{NH}_{4} \mathrm{Cl}$ in Form von weissem Nebel bildete sich nach ca. 5 min wesentlich näher bei $\mathrm{HCl}$ (Molmasse $37 \mathrm{~g} / \mathrm{mol}$ ), als bei $\mathrm{NH}_{3}$ (Molmasse $17 \mathrm{~g} / \mathrm{mol}$ ) Nach weiteren $1-3$ h schob sich die Reaktionsfront in Richtung $\mathrm{HCl}$-Quelle vor. Gleichzeitig schlug sich das feste, weisse Reaktionsprodukt $\mathrm{NH}_{4} \mathrm{Cl}$, mit reproduzierbar regelmäisigen Streifen auf der Wandoberfläche des Rohres nieder.

\subsection{Variationen}

Die regelmässigen Strukturen wurden in verschieden dicken Glasröhren $(61,37,25,11$ mm Durchmesser), und selbst in stehenden Glas-Zylindern beobach-

Tabelle. Untersuchte Kombinationen von Reaktanden

a) + : Experiment durchgeführt. $120 \mathrm{mln}$ bei $20^{\circ}$ bei der Gasphasenreaktion von $\mathrm{HCl}$ mit $\mathrm{NH}_{3}$
Chimia 45 (1991) 269-270

() Schweiz. Chemiker-Verhand: ISSN 0009-4293

tet. Ebenso sind verschiedene Kombinationen der Reaktionskomponenten eingesetzt worden. So wurden die in der Tabelle aufgeführten Kombinationen von leichtflüchtigen Reaktanden verwendet. Bei allen Experimenten konnten die streifenförmigen Ablagerungen an der Wandinnenseite beobachtet werden.

Die Temp., eine entscheidende Grösse bei der Diffusionsgeschwindigkeit, wurde von $+50^{\circ}$ bis $+7^{\circ}$ variiert. Dabei wurde das Reaktionsrohr mit einem Wassermantel auf die entsprechende Temperatur gebracht. Die Zugabe der beiden Reaktanden geschah gleichzeitig über Schläuche, nachdem sich das Temperaturgleichgewicht eingespielt hatte. Mit dieser Versuchsanordnung konnten auch Phänomene ausgeschlossen werden, die in Kundt'schen Röhren beobachtet werden können.

\subsection{Thermische Dissoziation mit} anschliessender Rïckreaktion

Mit $\mathrm{NH}_{4} \mathrm{Cl}$ wurden auch Versuche mit thermischer Dissoziation zu $\mathrm{NH}_{3}$ und $\mathrm{HCl}$, und anschliessender Rückreaktion zu $\mathrm{NH}_{4} \mathrm{Cl}$ durchgeführt. Trockenes $\mathrm{NH}_{4} \mathrm{Cl}$ hat in der Reaktionzone kein $\mathrm{H}_{2} \mathrm{O}$, damit ist ein Katalysator dieser Reaktion nichı vorhanden. Bei den Versuchen wurde eine Probe von $1 \mathrm{~g} \mathrm{NH} \mathrm{Nl}_{4}$, in einem einseitig geschlossenen Glasrohr von $22 \mathrm{~mm}$ Durchmesser, über dem Bunsenbrenner mit kleiner Flamme erhitzt. Es bildete sich auch hier eine ähnlich strukturierte Reaktionszone (Wirbelbildung), wie bei den Versuchen mit getrennten $\mathrm{HCl}$ - und $\mathrm{NH}_{3}$-Quellen. Eine nichtkontinuierliche Ablagerung von Reaktionsprodukt konnte bei diesen Versuchen manchmal vermutet, aber nie reproduzierbar nachgewiesen werden.

\section{Beobachtungen}

Bei allen Versuchen schied sich das Reaktionsprodukt mit streifenförmigem Muster ab. Nur am Rohrboden war eine kontinuierliche Ablagerung zu beobachten. Die Streifen waren mit dem oberen Teil der schwereren Komponente zugeneigt.

Die Abstände der Ringe von abgelagertem Produkt wurden mit zunehmender Reaktionsdauer immer kleiner. Bei höheren Temperaturen waren die Strukturen nur geringfügig flacher (kleinerer Winkel der Streifen zur Rohrachse), als bei $20^{\circ}$. Der Abstand des Reaktionsbeginns von der $\mathrm{HCl}$ Quelle verringerte sich, bei der Temperaturerhöhung um $30^{\circ}$, von c $a .40 \mathrm{~cm}$ auf c $a$. $20 \mathrm{~cm}$. Bei der tiefsten Temperatur von $+7^{\circ}$

\begin{tabular}{lllll}
\hline Säure & Base $\left.^{\mathrm{a}}\right)$ & & & \\
\cline { 2 - 5 } & $\mathrm{NH}_{3}$ & $\mathrm{Me}_{2} \mathrm{NH}$ & $\mathrm{Et}_{2} \mathrm{NH}$ & Pyridin \\
\hline $\mathrm{HCl}$ & + & + & + & + \\
$\mathrm{HBr}$ & + & + & - & - \\
$\mathrm{HNO}_{3}$ & + & - & - & - \\
\hline
\end{tabular}

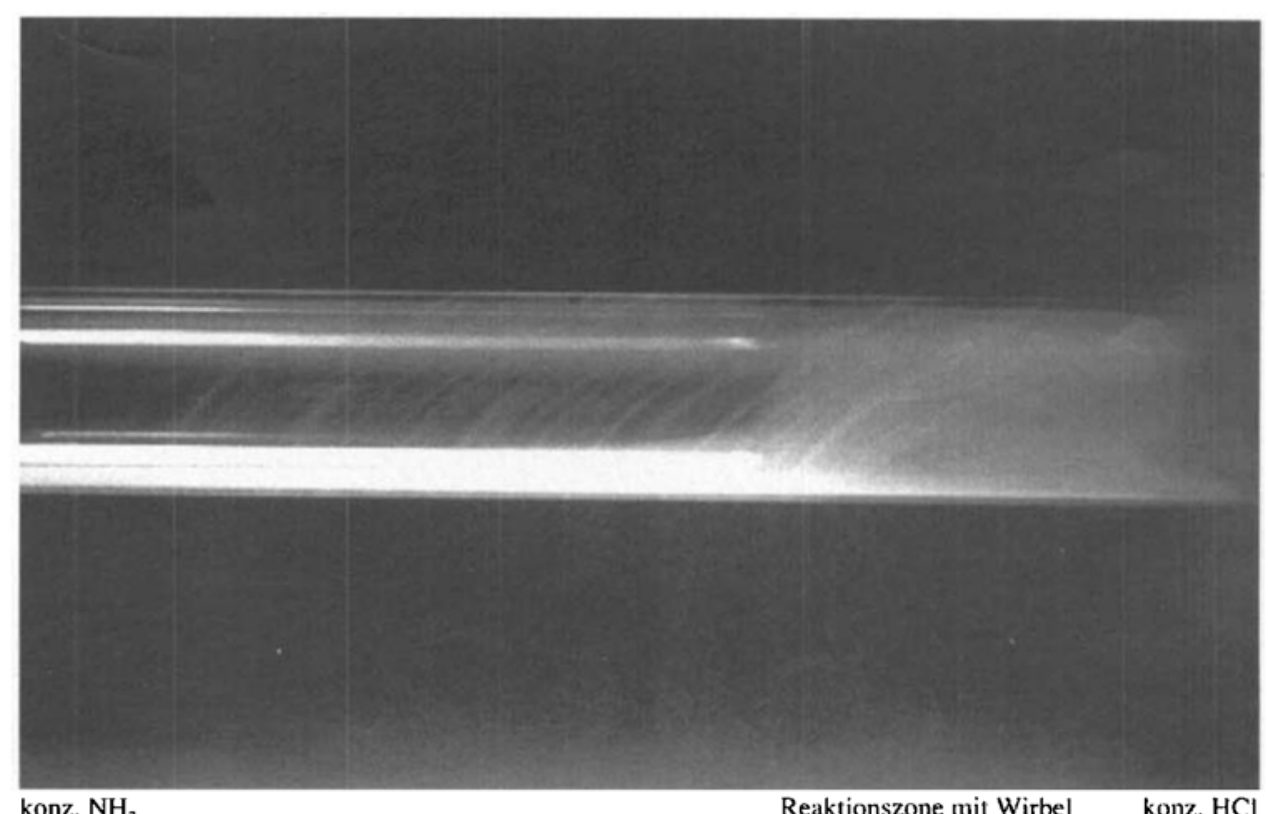

Figur. Strukturierte $\mathrm{NH}_{4} \mathrm{Cl}$-Ablagerungen in einem Glasrohr von $37 \mathrm{~mm}$ Durchmesser und $153 \mathrm{~cm}$ Länge, nach 
waren die Niederschläge ausserordentlich schwach, die Ringbildung wies aber zur Rohrachse einen grösseren Winkel auf. Gleichzeitig war eine stärkere Ablagerung am Rohrboden zu beobachten.

\section{Interpretation}

Die Bildung von $\mathrm{NH}_{4} \mathrm{Cl}$ in der Gasphase ist eine Gleichgewichtsreaktion mit einer Gleichgewichtskonstanten:

$\mathrm{K}=\left[\mathrm{NH}_{3}\right] \cdot[\mathrm{HCl}]=1,22 \cdot 10^{-5}$ bei $200^{\circ}$ [12]. Die Temperatur der thermischen Dissoziation von Ammonium-Salzen ist umso tiefer, je basischer das Anion ist. Bildung und Zerfall von $\mathrm{NH}_{4} \mathrm{Cl}$ sind durch Feuchtigkeit katalysiert. Wasserdampf lag als Katalysator bei allen Experimenten vor, bei welchen die Edukte in der Röhre am Anfang getrennt waren, da mindestens eine Komponente in wässriger Lösung vorlag.

Die Ringe der Ablagerungen des festen Reaktionsprodukts sind schräg zum Reaktanden mit der höheren Molmasse geneigt. Dies zeigt, dass die schwerere Komponente im Glasrohr unten rascher diffundiert, als oben. Die leichtere Komponente schiebt sich im oberen Teil der Röhre, wegen der grösseren Diffusionsgeschwindigkeit, schneller vor. Bei der Reaktion kann als Folge ein rollendes Vorwärtsschieben in Form eines Wirbels beobachtet werden. Die
Drehrichtung läuft oben von der leichteren, und unten von der schwereren Komponente weg. Die Ringe der Ablagerungen werden mit fortschreitender Reaktion immer flacher. Das deutet darauf hin, dass sich die leichtere Komponente, mit zunehmender Reaktionsdauer, relativ zur schwereren Komponente oben immer rascher vorwärtsbewegt. Die kleiner werdenden Abstände der Ringe könnten damit erklärt werden, dass die Diffusionszeit der schwereren Komponente durch die abnehmende Distanz zur Reaktionszone mit fortschreitender Reaktionsdauer abnimmt. Es kann als Folgerung angenommen werden, dass die Reaktionsgeschwindigkeit viel grösser sein muss, als die Diffusionsgeschwindigkeit, was zur Folge hat, dass eine Zone bei der Reaktion an Reaktanden verarmt. Trotzdem bleibt unerklärt, weshalb es zu periodischen Ablagerungen des Reaktionsproduktes kommen kann.

Interessant ist die Beobachtung, dass sich das, im Vergleich zu $\mathrm{HCl}$ doppelt so schwere Pyridin, anfänglich unter das $\mathrm{HCl}-\mathrm{Gas}$ schiebt. Mit der Zeit stellen sich aber die Ablagerungen senkrecht zur Rohrachse ein und zeigen am Schluss wieder, die auch mit $\mathrm{NH}_{3}$ gefundene Lage. Der Winkel der Ringe, relativ zur Rohrachse scheint von der Gasdichte nur am Anfang der Reaktion bestimmt zu sein.
[1] P. Davies, 'Prinzip Chaos', C. Bertelsmann Verlag, München, 1988.

[2] H. Haken, 'Erfolgsgeheimnisse der Natur: Synergetik die Lehre vom Zusammenwirken', UIIstein-Verlag, Frankfurt am Main-Berlin, 1988.

[3] W. Kleber, 'Einführung in die Kristallographie', VEB Verlag Technik, Berlin, 1965, S. 266.

[4] J.F. Lefelhocz, J. Chem. Educ' 1972, 49, 312.

[5] S. Scott, New Scientist, 2. December 1989, 53.

[6] F. Bukatsch, O.P. Krätz, G. Probeck, J. Schwankner, 'So interessant ist Chemie', Aulis Verlag Deubner \& Co KG, Köln, 1987, S. 209.

[7] D.M.L. Goodgame, A.M. Khaled, C.A. O'Mahoney, D.I. Williams, J. Chem. Soc. 1990, 851 .

[8] J.R. Melrose, D.B. Hibbert, R.C. Ball, Phys. Rev'. Lett. 1990, 3009

[9] F. Lindeblatt, 'Chemie experimentell', Industrie Druck GmbH Verlag, Göltingen, 1972, S. 58.

10] K. Häusler, H. Rampf, ' 270 chemische Schulversuche mit Einführung in die Laborpraxis', R. Oldenburg Verlag, München, 1976, S. 132.

[11] Serendipity: 'the gift of finding valuable or agreeable things not sought for' aus dem persischen Märchen 'The Tree Princes of Serendip' interpretiert von Hugh Warpole: 'These tree princes on their travel through Serendip (heute Sri Lanka) were always making discoveries by accidents and sagacity, of things they were not in quest of.. you must observe that no discovery of any thing you are looking for comes under this descripion.'

[12] G. Schwarzenbach, 'Allgemeine und anorganische Chemie', Georg Thieme Verlag, Stuttgart, 1950, S. 136. 


\section{Two Silver Medals for Switzerland}

Unbelievable but true! Little Switzerland has obtained two silver medals in the last International Chemistry Olympiad, in Lodz, Poland, July 7-15, 1991: the best result it has ever achieved in any Olympiad so far. This remarkable performance is due to two extraordinary students: André Rouge from Romanel-sur-Lausanne and Marco Ziegler from Sulgen (TG)

Although these friendly competitions exist since 1968, Switzerland has only decided in 1986 to participate. But there was'nt any real success until last year in Paris where our country got its first medal, a bronze one, thanks to Marco Ziegler, a brilliant self-made chemistry student, who managed to study chemistry in his own laboratory at home.

The International Chemistry Olympiad is a competition organized so that each country who wants to participate can select, train, and send a national team of 4 students coming from general pre-university classes. There is a competition each year in a different city: Halle (DDR) 1989, Paris 1990, and Lodz (Poland) 1991. Both practical tasks and theoretical problems are presented to the candidates. After the corrections it comes to the final classification: the top ten get gold medals, the next twenty get a silver medal, and finally the following thirty ones get a bronze one.

In 1991120 students took part; 30 different countries were represented, the most from Europe, three from America (Canada, USA, Cuba) and four from the Far East (China, Thailand, Singapore, Australia). The problems are added in the annex to the present report. The first medals went to China, ranks 1,2 , and 5 , with 95,95 , and 92 points, respectively. The first Western student is a Dutch in rank 6. André Rouge is the 9th Western student with 83 points, and Marco Ziegler the 16 th with 79.5 points. It might be worth noticing that there were also students coming from Lituania, Latvia, and Slovenia, all for the first time

Beside of the competitions all participants were invited to visit Warsaw, churches (Czestochowa's Black Virgin), museums (Chopin's native house), and other interesting places. The obviously most impor- tant experience of such olympiads is probably the feeling of friendship that arises among bright students who spare the same enthusiasm for chemistry.

Next year the 24th Chemistry Oympiad will happen in Washington, DC, USA. New countries will be present, like Kuwait, Korea, Taiwan, and New-Zealand. Switzerland will also take part. The only trouble is the lack of accompanying teachers. So far the whole training comes from Lausanne, since the only two teachers involved are from this city. It is an absolute must to find at least one other teacher from the German speaking part of Switzerland to help the 'Waadtländer'. Who will accept this task and accompany our team in America next year? Who? Please write to any of the two teachers involved:

Dr. Maurice Cosandey, Noyers 2 C, 1131 Tolochenaz, or Dr. Blenda Weibel, Coutzet 14, 1094 Paudex.

\section{Theoretical Task 1}

Explain why $0.1 \mathrm{~mol}$ of $\mathrm{Tl}_{2} \mathrm{~S}$ (solubility product $10^{-20}$ ) can be dissolved in $1 \mathrm{dm}^{3}$ of a $1 \mathrm{M}$ soln. of any strong non-coordinating monoacid.

Explain why $0.1 \mathrm{~mol}$ of $\mathrm{CuS}$ (solubility product $10^{-35}$ ) is not dissolved in $1 \mathrm{dm}^{3}$ of $1 \mathrm{M} \mathrm{HNO}_{3}$, using the following numerical data:

- Acidity constants: $\mathrm{p} K_{\mathrm{a}}\left(\mathrm{H}_{2} \mathrm{~S}\right)=7$ $\mathrm{p} K_{\mathrm{a}}\left(\mathrm{HS}^{-)}=13\right.$

- Standard redox potentials: $E^{\circ}(\mathrm{S} /$ $\left.\mathrm{S}^{2-}\right)=-0.48 \mathrm{~V} ; E^{\circ}\left(\mathrm{NO}_{3}-\mathrm{NO}_{\mathrm{aq}}\right)=$ $0.96 \mathrm{~V}$

- Solubility of NO in water at $298 \mathrm{~K}$ $=0.0253 \mathrm{M}$.

\section{Theoretical Task 2}

2.1. A purified polymer $\mathbf{X}$ contains $88.25 \% \mathrm{C}$ and $11.75 \% \mathrm{H}$; it may react with bromine and ozone. Its pyrolysis produces a volatile liquid $Y$ of the same composition (88.25\% $\mathrm{C}$ and $11.75 \% \mathrm{H})$ with a yield of $58 \%$. Other products are also obtained due to further decomposition of $\mathbf{Y}$ or Diels-Alder reaction on $\mathbf{Y}$ Vapor density of $\mathbf{Y}$ is 34 times higher than of $\mathrm{H}_{2}$. $Y$ reacts with $\mathrm{Br}_{2}$ and yields a compound containing $82.5 \% \mathrm{Br}$. Action of ozone on $\mathbf{Y}$, followed by a soft reduction, yields two compounds $\mathbf{A}$ and $\mathbf{B}$, in a ratio $\mathbf{A} / \mathbf{B}=2: 1$. Only $\mathbf{B}$ reacts positively in the iodoform test according to the following equation :

$\mathrm{R}-\mathrm{CO}-\mathrm{CH}_{3}+3 \mathrm{I}_{2}+4 \mathrm{NaOH} \rightarrow$ $\mathrm{R}-\mathrm{COONa}+\mathrm{CHI}_{3}+3 \mathrm{H}_{2} \mathrm{O}+3 \mathrm{NaI}$

What is the molecular formula and the molar mass of $\mathbf{Y}$ ?

What is the structural formula of $\mathbf{Y}, \mathbf{A}$, and $\mathbf{B}$ ?

What is the equation of the reaction of $\mathbf{Y}$ with $\mathrm{Br}_{2}$ ?

2.2. Catalytic hydrogenation of $13.6 \mathrm{~g}$ of $\mathrm{X}$ consumes $0.2 \mathrm{~mol}$ of $\mathrm{H}_{2}$ Ozonolysis of $\mathbf{X}$ yields after sof reduction a compound $\mathbf{Z}$ containing $60 \% \mathrm{C}$ and $8.0 \% \mathrm{H}$. What is the formula for $\mathbf{Z}$ and the degree of unsaturation of $X$ ?

2.3. Compound $\mathbf{Z}$ reacts positively with Fehling's soln. Oxidation of $\mathrm{Z}$ yields an acid $\mathrm{C}$. When dissolved $0.116 \mathrm{~g}$ of $\mathrm{C}$ is neutralized by $0.001 \mathrm{~mol}$ of $\mathrm{KOH}$

In the iodoform test $2.90 \mathrm{~g}$ of $\mathbf{C}$ yields $9.85 \mathrm{~g}$ of iodoform $\mathrm{CHI}_{3}$, and a soln. which produces a compound $\mathrm{E}$ after acidification. What is the molar mass of $\mathrm{C}$ ?

2.4. When heated, $\mathbf{E}$ loses water and produces $\mathbf{F}$. Both $\mathbf{E}$ and $\mathbf{F}$ yield the same compound $\mathbf{G}\left(\mathrm{C}_{8} \mathrm{H}_{14} \mathrm{O}_{4}\right)$ when heated to reflux with ethano in excess under acidic conditions. What are the structures of $\mathbf{C}, \mathbf{E}, \mathbf{F}, \mathbf{G}$ and how is the reaction scheme for the transformation of $\mathbf{E}$ to $\mathbf{G}$ ?

2.5. X can show stereoisomerism. Present a part of its structure with at least three monomer units for two stereoisomers of $\mathrm{X}$

\section{Theoretical Task 3}

A silver chloride electrode $\mathrm{Ag}$ / $\mathrm{AgCl} / \mathrm{Cl}^{-}$is connected to a calomel electrode $\mathrm{Hg} / \mathrm{Hg}_{2} \mathrm{Cl}_{2} / \mathrm{Cl}^{-}$to promote a cell $(-) \mathrm{Ag} / \mathrm{AgCl} / \mathrm{KCl} /$ $\mathrm{Hg}_{2} \mathrm{Cl}_{2} / \mathrm{Hg}(+)$ whose e.m.f. is 0.0455 $\mathrm{V}$ at $T=298 \mathrm{~K}$. When $T$ increases the following e.m.f. change is observed: $d E^{\circ} / d T=3.3810^{-4} \mathrm{VK}^{-1}$.

3.1. What are the equations of the reactions occurring in the cell?

3.2. What is the corresponding free enthalpy change $\Delta G^{\circ}$ ?

3.3. What are the corresponding enthalpy and entropy changes $\Delta \mathrm{H}$ and $\Delta \mathrm{S}$, using the following relation: $\Delta \mathrm{S}=\mathrm{nFE} d E / d T$ ?

3.4. Knowing the solubility product $\mathrm{K}_{\mathrm{s}}(\mathrm{AgCl})=1.7310^{-10}$, and the standard potential $E^{\circ}\left(\mathrm{Ag} / \mathrm{Ag}^{+}\right)=$ $0.799 \mathrm{~V}$, calculate the standard potential of the silver chloride electrode $\mathrm{Ag} / \mathrm{AgCl} / \mathrm{Cl}^{-}$

Establish the relation between $E^{\circ}\left(\mathrm{Ag} / \mathrm{Ag}^{+}\right)$and $E^{\circ}(\mathrm{Ag} / \mathrm{AgCl} /$ $\left.\mathrm{Cl}^{-}\right)$.

3.5. Calculate the solubility product for $\mathrm{Hg}_{2} \mathrm{Cl}_{2}$ knowing $E^{\circ}(\mathrm{Hg} /$ $\left.\mathrm{Hg}_{2}{ }^{2+}\right)=0.798 \mathrm{~V}$.
Theoretical Task 4

Stable state energies $E_{\mathrm{n}}$ for $\mathrm{H}$ atoms are given by the formula:

$E_{\mathrm{n}}=-2.1810^{-18} / \mathrm{n}^{2}$, in J, if $\mathrm{n}$ is the principal quantum number.

4.1. What is the energy difference between the states $n=2$ and $n=1$, and then between the states $n=6$ and $n=1$ ?

4.2. In which spectral zone are situated the preceeding transitions, called Lyman transitions?

4.3. Can a photon emitted in the transition from $n=6$ to $n=1$ ionize another $\mathrm{H}$ atom? Can it ionize a $\mathrm{Cu}$ atom from solid copper, where the extraction energy of an electron is $7.4410^{-19} \mathrm{~J}$ ?

4.4. Calculate the de Broglie wavelength of the electrons emitted from copper.

\section{Theoretical Task 5}

$0.25 \mathrm{~mol}$ of a hydrocarbon $A$ is heated to $1000 \mathrm{~K}$ in an iron tube containing pumice. It is decomposed in a main reaction (yield $80 \%$ ) producing $15.4 \mathrm{~g}$ of a cyclic compound B and $2.40 \mathrm{dm}^{3}$ of $\mathrm{H}_{2}$ (at $295 \mathrm{~K}$ and $102 \mathrm{kPa}$ ).

In the presence of a Lewis acid, $\mathbf{B}$ reacts with halogen and produces halogenated derivatives $\mathbf{C}, \mathbf{D}, \mathbf{E}, \mathbf{F}$, and $\mathbf{G}$. Each member of this series C- $\mathbf{G}$ has one halogen more than the preceding one. For $\mathbf{C}-\mathbf{F}$ only one isomer is obtained. For $\mathbf{G}$ three different isomers are obtained: $\mathbf{G}_{1}, \mathbf{G}_{2}$, and $\mathbf{G}_{3}$. All these compounds are optically active. But for $\mathbf{C}$ to $\mathbf{F}$ racemization is so easy that this phenomenon cannot be observed. Racemization is difficult for $\mathbf{G}_{\mathbf{1}}, \mathbf{G}_{\mathbf{2}}$ and above all for $\mathbf{G}_{3}$. The mass spectrum of $\mathbf{E}$ shows only three important peaks with intensities in the ratio of $1: 1: 0.3$

5.1. Determine the structure of $A$, $B, C, D, E, F, G_{1}, G_{2}, G_{3}$, taking into account the following two informations:

- When $\mathbf{B}$ reacts a weak activating effect is observed, and $\mathrm{k}($ ortho) is much higher than $\mathrm{k}$ (para)

- Compounds D and F have conformations with symmetry centers.

5.2. Which is the halogen involved?

5.3. Draw the rotational isomers for $\mathbf{D}$ using different values for the dihedral angle.

5.4. Organize $\mathbf{G}_{1}, \mathbf{G}_{\mathbf{2}}$, and $\mathbf{G}_{\mathbf{3}}$ by increasing the racemization difficulty.

\section{Theoretical Task 6}

A catalytic reactor is used to convert $\mathrm{SO}_{2}$ and air into $\mathrm{SO}_{3}$ so that the exit gases contain $10 \%$ of $\mathrm{SO}_{3}$ in volume. These gases are then ab- 
sorbed so that $\mathrm{SO}_{3}$ is transformed either into sulfuric acid $(98 \%)$ or into oleum (pure sulfuric acid containing $20 \%$ of $\mathrm{SO}_{3}$ in mass)

6.1. If oleum is the only final product, how much water is necessary to treat $1000 \mathrm{~m}^{3}$ of gas getting out of the catalytic reactor. What is the mass of the oleum produced?

6.2. Same questions if sulfuric acid $(98 \%)$ is produced instead of oleum.

6.3. Oleum and sulfuric acid can also be produced as a mixture with a mass ratio $X=\mathrm{ml}_{1} / \mathrm{m}_{2}$, where $m_{1}$ and $\mathrm{m}_{2}$ are the masses of oleum and sulfuric acid, resp.

6.3.1. Determine the algebraic expression $Y=f(X)$ relating $X$ and the mass $Y$ of water consumed to treat $1000 \mathrm{~m} 3$ of gaseous mixture.

6.3.2. Show that the values obtained in Chapt. 6.1 and 6.2 are in agreement with this expression.

\section{Practical Task I}

The student is provided with two aq. solns.: $\mathrm{NaOH}$ and a weak monoacid both c $a .0 .1 \mathrm{~m}$. Two indicators are also available: methylorange and phenolphthaleine. The student must develop his own method to determine the $\mathrm{p} K_{\mathrm{a}}$ value of the unknown acid. Only one measurement can be carried out with a pH meter.

\section{Practical Task 2}

The student must build a Daniell cell with $\mathrm{Zn}, \mathrm{Cu} . \mathrm{CuSO}_{4}$, and $\mathrm{ZnSO}_{4}$ sons., and check its e.m.f. After that he/she must add excess $\mathrm{NH}_{3}$ to the $\mathrm{Cu}$ soln., then to the $\mathrm{Zn}$ soln., measure all e.m.f. and determine the solubility constants of the complex ions.

Maurice Cosandey

\section{Schweizerischer Chemiker-Verband Schweizerische Chemische Gesellschaft Association Suisse des Chimistes Société Suisse de Chimie Swiss Association of Chemists Swiss Chemical Society}

Preannouncement

6th International Seminar on

\section{Modern Synthetic Methods}

May 4/5, 1992. Interlaken, Switzerland

Chairman: Prof. Rolf Scheffold, University of Bern

Topics in Carbanion Chemistry

Topics in Carbohydrate Chemistry

The detailed programme will be available in Dezember 1991:

Secretary's Office for Symposia

c/o Institute of Organic Chemistry, University of Bern

Freiestrasse 3

CH-3012 Bem

Tel. 0316543 11, Fax 031654499

\section{Herbstversammiung in Bern}

\section{Assemblée d'automne à Berne}

18. Oktober/octobre 1991

Universität Bern

Université de Berne

- Geschäftlicher Teil

- Vorträge und/oder Postersessionen in den Sektionen für

Organische Chemie

Medizinische Chemie

Radiochemie

Physikalische Chemie

Computerunterstützte Chemie
Woker-Strasse 5 (vis-à-vis Freiestrasse) statt.

Im 1.-4. Stock der Chemischen Institute sind die Poster der Sektion für Anorganische Chemie und Koordinationschemie und die der Analytischen Chemie aufgestellt.

Im 5. Stock präsentiert die Gruppe «Computerunterstïtzter Unterricht in der Chemie» der Kommission für Unterrichtsfragen im Schweiz. Komitee für Chemie Personalcomputer-Software für den Unterricht.

Les conférences auront lieu dans les auditoires U 113, $\mathrm{Ne} \mathrm{16,S} \mathrm{379,} \mathrm{S}$ 481 et dans le «Klubraum» des Instituts de Chimie de l'Université de Berne, Freiestrasse 3, et dans le «Gemeinschaftshörsaal des Physiologischen Instituts der Universität» et le «Aula Muesmatt», GertrudWoker-Strasse 5 (vis-à-vis Freiestrasse).

Les posters de la section de chimie minérale et de coordination et ceux de chimie analytique seront placés au ler-4e étage des Instituts de Chimie. Le «Study Group on Computer Assisted Teaching” de la Commission pour l'enseignement, Comité Suisse de la Chimie présentera des logiciels pour l'instruction assistée par l'ordinateur au 5e étage.

Während der Mittagspause ist kein gemeinsames Essen vorgesehen.

Il n'y aura pas de repas en commun pendant la pause de midi.

Allfällige Anfragen bitten wir an Dr. E. Zass zu richten: ETH sZürich, 8092 Zürich, Telefon 01/256 2964

Pour tous renseignements complémentaires s'adresser au $\mathrm{Dr}$. $E$. Zass, ETH Zürich, 8092 Zürich, tél. 01/256 2964
Schweizerische Vereinigung dipl. Chemiker HTL Association Suisse des Chimistes Diplomés ETS

\section{SVCT - Fachtagung 1991}

\section{Sicherheit in der chemischen Industrie}

Mittwoch, 30. Oktober 1991,Auditorium 510, Sandoz AG Basel

Dr. P. Jakober, Ing.-Schule Burgdorf

Sicherheit: Ein Begriff im Wandel der Zeit

W. Jezler, F. Hoffmann-La Roche $A G$

Risikoanalyse

Dr. R. Klaus, Sicherheitsinspektorat BL

Risikokataster

Dr. M. Schiess, BUWAL

Störfallverordnung: Betriebe mit Stoffen, Erzeugnissen oder Sonderabfällen

H. Stahel, Koord. für Störfallvorsorge ZH

Vollzug der Störfallverordnung auf Kantonsebene

D. Kurz, Krebs \& Co. AG

Massnahmen zur Störfallverminderung in allen Unternehmensbereichen

B. Hersche, GSS Riskmanagement AG

Information - Voraussetzung im Siörfall und Führungsinstrument

Dr. B. Glutz, Sandoz Pharma AG

Der Chemiker, Unternehmer zwichen Ehre und Risiko

Dr. J. Randegger, Ciba-Geigy' $A G$

Heutige Anforderungen an das Sicherheitsmanagement in der chemischen Industrie

Dr. P. Marbet, Sandoz AG

Massnahmen im Störfall

Dr. D. Schaub, Anwaltsbüro BS

Haftung für Betriebsunfälle: Wer wird wie zur Verantwortung gezogen?

Dr. H.Fehr

Schadenereignis und Öffentlichkeit; immaterielle Folgen

Die Vorträge finden in den Hörsälen U 113, NE 16, S 379, S 481 und im Klubraum der Chemischen Institute der Universität Bern, Freiestrasse 3, sowie im Gemeinschaftshörsaal des Physiologischen Instituts der Universität und in der Aula Muesmatt, beide Gertrud-
Dr. D. Mühlemann, Glauser Studer Stüssi AG

Was ist zu tun? Sicherheit Leben - Verantwortung übernehmen

Anmeldung und Information:

SVCT, Postfach 46, CH-4007 Basel

Telefon 061/688 4336 und 061/324 II 1 I 
sorbed so that $\mathrm{SO}_{3}$ is transformed either into sulfuric acid $(98 \%)$ or into oleum (pure sulfuric acid containing $20 \%$ of $\mathrm{SO}_{3}$ in mass)

6.1. If oleum is the only final product, how much water is necessary to treat $1000 \mathrm{~m}^{3}$ of gas getting out of the catalytic reactor. What is the mass of the oleum produced?

6.2. Same questions if sulfuric acid $(98 \%)$ is produced instead of oleum.

6.3. Oleum and sulfuric acid can also be produced as a mixture with a mass ratio $X=\mathrm{ml}_{1} / \mathrm{m}_{2}$, where $m_{1}$ and $\mathrm{m}_{2}$ are the masses of oleum and sulfuric acid, resp.

6.3.1. Determine the algebraic expression $Y=f(X)$ relating $X$ and the mass $Y$ of water consumed to treat $1000 \mathrm{~m} 3$ of gaseous mixture.

6.3.2. Show that the values obtained in Chapt. 6.1 and 6.2 are in agreement with this expression.

\section{Practical Task I}

The student is provided with two aq. solns.: $\mathrm{NaOH}$ and a weak monoacid both c $a .0 .1 \mathrm{~m}$. Two indicators are also available: methylorange and phenolphthaleine. The student must develop his own method to determine the $\mathrm{p} K_{\mathrm{a}}$ value of the unknown acid. Only one measurement can be carried out with a pH meter.

\section{Practical Task 2}

The student must build a Daniell cell with $\mathrm{Zn}, \mathrm{Cu} . \mathrm{CuSO}_{4}$, and $\mathrm{ZnSO}_{4}$ sons., and check its e.m.f. After that he/she must add excess $\mathrm{NH}_{3}$ to the $\mathrm{Cu}$ soln., then to the $\mathrm{Zn}$ soln., measure all e.m.f. and determine the solubility constants of the complex ions.

Maurice Cosandey

\section{Schweizerischer Chemiker-Verband Schweizerische Chemische Gesellschaft Association Suisse des Chimistes Société Suisse de Chimie Swiss Association of Chemists Swiss Chemical Society}

Preannouncement

6th International Seminar on

\section{Modern Synthetic Methods}

May 4/5, 1992. Interlaken, Switzerland

Chairman: Prof. Rolf Scheffold, University of Bern

Topics in Carbanion Chemistry

Topics in Carbohydrate Chemistry

The detailed programme will be available in Dezember 1991:

Secretary's Office for Symposia

c/o Institute of Organic Chemistry, University of Bern

Freiestrasse 3

CH-3012 Bem

Tel. 0316543 11, Fax 031654499

\section{Herbstversammiung in Bern}

\section{Assemblée d'automne à Berne}

18. Oktober/octobre 1991

Universität Bern

Université de Berne

- Geschäftlicher Teil

- Vorträge und/oder Postersessionen in den Sektionen für

Organische Chemie

Medizinische Chemie

Radiochemie

Physikalische Chemie

Computerunterstützte Chemie
Woker-Strasse 5 (vis-à-vis Freiestrasse) statt.

Im 1.-4. Stock der Chemischen Institute sind die Poster der Sektion für Anorganische Chemie und Koordinationschemie und die der Analytischen Chemie aufgestellt.

Im 5. Stock präsentiert die Gruppe «Computerunterstïtzter Unterricht in der Chemie» der Kommission für Unterrichtsfragen im Schweiz. Komitee für Chemie Personalcomputer-Software für den Unterricht.

Les conférences auront lieu dans les auditoires U 113, $\mathrm{Ne} \mathrm{16,S} \mathrm{379,} \mathrm{S}$ 481 et dans le «Klubraum» des Instituts de Chimie de l'Université de Berne, Freiestrasse 3, et dans le «Gemeinschaftshörsaal des Physiologischen Instituts der Universität» et le «Aula Muesmatt», GertrudWoker-Strasse 5 (vis-à-vis Freiestrasse).

Les posters de la section de chimie minérale et de coordination et ceux de chimie analytique seront placés au ler-4e étage des Instituts de Chimie. Le «Study Group on Computer Assisted Teaching" de la Commission pour l'enseignement, Comité Suisse de la Chimie présentera des logiciels pour l'instruction assistée par l'ordinateur au 5e étage.

Während der Mittagspause ist kein gemeinsames Essen vorgesehen.

Il n'y aura pas de repas en commun pendant la pause de midi.

Allfällige Anfragen bitten wir an Dr. E. Zass zu richten: ETH sZürich, 8092 Zürich, Telefon 01/256 2964

Pour tous renseignements complémentaires s'adresser au $\mathrm{Dr}$. $E$. Zass, ETH Zürich, 8092 Zürich, tél. 01/256 2964
Schweizerische Vereinigung dipl. Chemiker HTL Association Suisse des Chimistes Diplomés ETS

\section{SVCT - Fachtagung 1991}

\section{Sicherheit in der chemischen Industrie}

Mittwoch, 30. Oktober 1991,Auditorium 510, Sandoz AG Basel

Dr. P. Jakober, Ing.-Schule Burgdorf

Sicherheit: Ein Begriff im Wandel der Zeit

W. Jezler, F. Hoffmann-La Roche $A G$

Risikoanalyse

Dr. R. Klaus, Sicherheitsinspektorat BL

Risikokataster

Dr. M. Schiess, BUWAL

Störfallverordnung: Betriebe mit Stoffen, Erzeugnissen oder Sonderabfällen

H. Stahel, Koord. für Störfallvorsorge ZH

Vollzug der Störfallverordnung auf Kantonsebene

D. Kurz, Krebs \& Co. AG

Massnahmen zur Störfallverminderung in allen Unternehmensbereichen

B. Hersche, GSS Riskmanagement AG

Information - Voraussetzung im Siörfall und Führungsinstrument

Dr. B. Glutz, Sandoz Pharma AG

Der Chemiker, Unternehmer zwichen Ehre und Risiko

Dr. J. Randegger, Ciba-Geigy' $A G$

Heutige Anforderungen an das Sicherheitsmanagement in der chemischen Industrie

Dr. P. Marbet, Sandoz AG

Massnahmen im Störfall

Dr. D. Schaub, Anwaltsbüro BS

Haftung für Betriebsunfälle: Wer wird wie zur Verantwortung gezogen?

Dr. H.Fehr

Schadenereignis und Öffentlichkeit; immaterielle Folgen

Die Vorträge finden in den Hörsälen U 113, NE 16, S 379, S 481 und im Klubraum der Chemischen Institute der Universität Bern, Freiestrasse 3, sowie im Gemeinschaftshörsaal des Physiologischen Instituts der Universität und in der Aula Muesmatt, beide Gertrud-
Dr. D. Mühlemann, Glauser Studer Stüssi AG

Was ist zu tun? Sicherheit Leben - Verantwortung übernehmen

Anmeldung und Information:

SVCT, Postfach 46, CH-4007 Basel

Telefon 061/688 4336 und 061/324 II 1 I 
sorbed so that $\mathrm{SO}_{3}$ is transformed either into sulfuric acid $(98 \%)$ or into oleum (pure sulfuric acid containing $20 \%$ of $\mathrm{SO}_{3}$ in mass)

6.1. If oleum is the only final product, how much water is necessary to treat $1000 \mathrm{~m}^{3}$ of gas getting out of the catalytic reactor. What is the mass of the oleum produced?

6.2. Same questions if sulfuric acid $(98 \%)$ is produced instead of oleum.

6.3. Oleum and sulfuric acid can also be produced as a mixture with a mass ratio $X=\mathrm{ml}_{1} / \mathrm{m}_{2}$, where $m_{1}$ and $\mathrm{m}_{2}$ are the masses of oleum and sulfuric acid, resp.

6.3.1. Determine the algebraic expression $Y=f(X)$ relating $X$ and the mass $Y$ of water consumed to treat $1000 \mathrm{~m} 3$ of gaseous mixture.

6.3.2. Show that the values obtained in Chapt. 6.1 and 6.2 are in agreement with this expression.

\section{Practical Task I}

The student is provided with two aq. solns.: $\mathrm{NaOH}$ and a weak monoacid both c $a .0 .1 \mathrm{~m}$. Two indicators are also available: methylorange and phenolphthaleine. The student must develop his own method to determine the $\mathrm{p} K_{\mathrm{a}}$ value of the unknown acid. Only one measurement can be carried out with a pH meter.

\section{Practical Task 2}

The student must build a Daniell cell with $\mathrm{Zn}, \mathrm{Cu} . \mathrm{CuSO}_{4}$, and $\mathrm{ZnSO}_{4}$ sons., and check its e.m.f. After that he/she must add excess $\mathrm{NH}_{3}$ to the $\mathrm{Cu}$ soln., then to the $\mathrm{Zn}$ soln., measure all e.m.f. and determine the solubility constants of the complex ions.

Maurice Cosandey

\section{Schweizerischer Chemiker-Verband Schweizerische Chemische Gesellschaft Association Suisse des Chimistes Société Suisse de Chimie Swiss Association of Chemists Swiss Chemical Society}

Preannouncement

6th International Seminar on

\section{Modern Synthetic Methods}

May 4/5, 1992. Interlaken, Switzerland

Chairman: Prof. Rolf Scheffold, University of Bern

Topics in Carbanion Chemistry

Topics in Carbohydrate Chemistry

The detailed programme will be available in Dezember 1991:

Secretary's Office for Symposia

c/o Institute of Organic Chemistry, University of Bern

Freiestrasse 3

CH-3012 Bem

Tel. 0316543 11, Fax 031654499

\section{Herbstversammiung in Bern}

\section{Assemblée d'automne à Berne}

18. Oktober/octobre 1991

Universität Bern

Université de Berne

- Geschäftlicher Teil

- Vorträge und/oder Postersessionen in den Sektionen für

Organische Chemie

Medizinische Chemie

Radiochemie

Physikalische Chemie

Computerunterstützte Chemie
Woker-Strasse 5 (vis-à-vis Freiestrasse) statt.

Im 1.-4. Stock der Chemischen Institute sind die Poster der Sektion für Anorganische Chemie und Koordinationschemie und die der Analytischen Chemie aufgestellt.

Im 5. Stock präsentiert die Gruppe «Computerunterstïtzter Unterricht in der Chemie» der Kommission für Unterrichtsfragen im Schweiz. Komitee für Chemie Personalcomputer-Software für den Unterricht.

Les conférences auront lieu dans les auditoires U 113, $\mathrm{Ne} \mathrm{16,S} \mathrm{379,} \mathrm{S}$ 481 et dans le «Klubraum» des Instituts de Chimie de l'Université de Berne, Freiestrasse 3, et dans le «Gemeinschaftshörsaal des Physiologischen Instituts der Universität» et le «Aula Muesmatt», GertrudWoker-Strasse 5 (vis-à-vis Freiestrasse).

Les posters de la section de chimie minérale et de coordination et ceux de chimie analytique seront placés au ler-4e étage des Instituts de Chimie. Le «Study Group on Computer Assisted Teaching" de la Commission pour l'enseignement, Comité Suisse de la Chimie présentera des logiciels pour l'instruction assistée par l'ordinateur au 5e étage.

Während der Mittagspause ist kein gemeinsames Essen vorgesehen.

Il n'y aura pas de repas en commun pendant la pause de midi.

Allfällige Anfragen bitten wir an Dr. E. Zass zu richten: ETH sZürich, 8092 Zürich, Telefon 01/256 2964

Pour tous renseignements complémentaires s'adresser au $\mathrm{Dr}$. $E$. Zass, ETH Zürich, 8092 Zürich, tél. 01/256 2964
Schweizerische Vereinigung dipl. Chemiker HTL Association Suisse des Chimistes Diplomés ETS

\section{SVCT - Fachtagung 1991}

\section{Sicherheit in der chemischen Industrie}

Mittwoch, 30. Oktober 1991,Auditorium 510, Sandoz AG Basel

Dr. P. Jakober, Ing.-Schule Burgdorf

Sicherheit: Ein Begriff im Wandel der Zeit

W. Jezler, F. Hoffmann-La Roche $A G$

Risikoanalyse

Dr. R. Klaus, Sicherheitsinspektorat BL

Risikokataster

Dr. M. Schiess, BUWAL

Störfallverordnung: Betriebe mit Stoffen, Erzeugnissen oder Sonderabfällen

H. Stahel, Koord. für Störfallvorsorge ZH

Vollzug der Störfallverordnung auf Kantonsebene

D. Kurz, Krebs \& Co. AG

Massnahmen zur Störfallverminderung in allen Unternehmensbereichen

B. Hersche, GSS Riskmanagement AG

Information - Voraussetzung im Siörfall und Führungsinstrument

Dr. B. Glutz, Sandoz Pharma AG

Der Chemiker, Unternehmer zwichen Ehre und Risiko

Dr. J. Randegger, Ciba-Geigy' $A G$

Heutige Anforderungen an das Sicherheitsmanagement in der chemischen Industrie

Dr. P. Marbet, Sandoz AG

Massnahmen im Störfall

Dr. D. Schaub, Anwaltsbüro BS

Haftung für Betriebsunfälle: Wer wird wie zur Verantwortung gezogen?

Dr. H.Fehr

Schadenereignis und Öffentlichkeit; immaterielle Folgen

Die Vorträge finden in den Hörsälen U 113, NE 16, S 379, S 481 und im Klubraum der Chemischen Institute der Universität Bern, Freiestrasse 3, sowie im Gemeinschaftshörsaal des Physiologischen Instituts der Universität und in der Aula Muesmatt, beide Gertrud-
Dr. D. Mühlemann, Glauser Studer Stüssi AG

Was ist zu tun? Sicherheit Leben - Verantwortung übernehmen

Anmeldung und Information:

SVCT, Postfach 46, CH-4007 Basel

Telefon 061/688 4336 und 061/324 II 1 I 
sorbed so that $\mathrm{SO}_{3}$ is transformed either into sulfuric acid $(98 \%)$ or into oleum (pure sulfuric acid containing $20 \%$ of $\mathrm{SO}_{3}$ in mass)

6.1. If oleum is the only final product, how much water is necessary to treat $1000 \mathrm{~m}^{3}$ of gas getting out of the catalytic reactor. What is the mass of the oleum produced?

6.2. Same questions if sulfuric acid $(98 \%)$ is produced instead of oleum.

6.3. Oleum and sulfuric acid can also be produced as a mixture with a mass ratio $X=\mathrm{ml}_{1} / \mathrm{m}_{2}$, where $m_{1}$ and $\mathrm{m}_{2}$ are the masses of oleum and sulfuric acid, resp.

6.3.1. Determine the algebraic expression $Y=f(X)$ relating $X$ and the mass $Y$ of water consumed to treat $1000 \mathrm{~m} 3$ of gaseous mixture.

6.3.2. Show that the values obtained in Chapt. 6.1 and 6.2 are in agreement with this expression.

\section{Practical Task I}

The student is provided with two aq. solns.: $\mathrm{NaOH}$ and a weak monoacid both c $a .0 .1 \mathrm{~m}$. Two indicators are also available: methylorange and phenolphthaleine. The student must develop his own method to determine the $\mathrm{p} K_{\mathrm{a}}$ value of the unknown acid. Only one measurement can be carried out with a pH meter.

\section{Practical Task 2}

The student must build a Daniell cell with $\mathrm{Zn}, \mathrm{Cu} . \mathrm{CuSO}_{4}$, and $\mathrm{ZnSO}_{4}$ sons., and check its e.m.f. After that he/she must add excess $\mathrm{NH}_{3}$ to the $\mathrm{Cu}$ soln., then to the $\mathrm{Zn}$ soln., measure all e.m.f. and determine the solubility constants of the complex ions.

Maurice Cosandey

\section{Schweizerischer Chemiker-Verband Schweizerische Chemische Gesellschaft Association Suisse des Chimistes Société Suisse de Chimie Swiss Association of Chemists Swiss Chemical Society}

Preannouncement

6th International Seminar on

\section{Modern Synthetic Methods}

May 4/5, 1992. Interlaken, Switzerland

Chairman: Prof. Rolf Scheffold, University of Bern

Topics in Carbanion Chemistry

Topics in Carbohydrate Chemistry

The detailed programme will be available in Dezember 1991:

Secretary's Office for Symposia

c/o Institute of Organic Chemistry, University of Bern

Freiestrasse 3

CH-3012 Bem

Tel. 0316543 11, Fax 031654499

\section{Herbstversammiung in Bern}

\section{Assemblée d'automne à Berne}

18. Oktober/octobre 1991

Universität Bern

Université de Berne

- Geschäftlicher Teil

- Vorträge und/oder Postersessionen in den Sektionen für

Organische Chemie

Medizinische Chemie

Radiochemie

Physikalische Chemie

Computerunterstützte Chemie
Woker-Strasse 5 (vis-à-vis Freiestrasse) statt.

Im 1.-4. Stock der Chemischen Institute sind die Poster der Sektion für Anorganische Chemie und Koordinationschemie und die der Analytischen Chemie aufgestellt.

Im 5. Stock präsentiert die Gruppe «Computerunterstïtzter Unterricht in der Chemie» der Kommission für Unterrichtsfragen im Schweiz. Komitee für Chemie Personalcomputer-Software für den Unterricht.

Les conférences auront lieu dans les auditoires U 113, $\mathrm{Ne} \mathrm{16,S} \mathrm{379,} \mathrm{S}$ 481 et dans le «Klubraum» des Instituts de Chimie de l'Université de Berne, Freiestrasse 3, et dans le «Gemeinschaftshörsaal des Physiologischen Instituts der Universität» et le «Aula Muesmatt», GertrudWoker-Strasse 5 (vis-à-vis Freiestrasse).

Les posters de la section de chimie minérale et de coordination et ceux de chimie analytique seront placés au ler-4e étage des Instituts de Chimie. Le «Study Group on Computer Assisted Teaching" de la Commission pour l'enseignement, Comité Suisse de la Chimie présentera des logiciels pour l'instruction assistée par l'ordinateur au 5e étage.

Während der Mittagspause ist kein gemeinsames Essen vorgesehen.

Il n'y aura pas de repas en commun pendant la pause de midi.

Allfällige Anfragen bitten wir an Dr. E. Zass zu richten: ETH sZürich, 8092 Zürich, Telefon 01/256 2964

Pour tous renseignements complémentaires s'adresser au $\mathrm{Dr}$. $E$. Zass, ETH Zürich, 8092 Zürich, tél. 01/256 2964
Schweizerische Vereinigung dipl. Chemiker HTL Association Suisse des Chimistes Diplomés ETS

\section{SVCT - Fachtagung 1991}

\section{Sicherheit in der chemischen Industrie}

Mittwoch, 30. Oktober 1991,Auditorium 510, Sandoz AG Basel

Dr. P. Jakober, Ing.-Schule Burgdorf

Sicherheit: Ein Begriff im Wandel der Zeit

W. Jezler, F. Hoffmann-La Roche $A G$

Risikoanalyse

Dr. R. Klaus, Sicherheitsinspektorat BL

Risikokataster

Dr. M. Schiess, BUWAL

Störfallverordnung: Betriebe mit Stoffen, Erzeugnissen oder Sonderabfällen

H. Stahel, Koord. für Störfallvorsorge ZH

Vollzug der Störfallverordnung auf Kantonsebene

D. Kurz, Krebs \& Co. AG

Massnahmen zur Störfallverminderung in allen Unternehmensbereichen

B. Hersche, GSS Riskmanagement AG

Information - Voraussetzung im Siörfall und Führungsinstrument

Dr. B. Glutz, Sandoz Pharma AG

Der Chemiker, Unternehmer zwichen Ehre und Risiko

Dr. J. Randegger, Ciba-Geigy' $A G$

Heutige Anforderungen an das Sicherheitsmanagement in der chemischen Industrie

Dr. P. Marbet, Sandoz AG

Massnahmen im Störfall

Dr. D. Schaub, Anwaltsbüro BS

Haftung für Betriebsunfälle: Wer wird wie zur Verantwortung gezogen?

Dr. H.Fehr

Schadenereignis und Öffentlichkeit; immaterielle Folgen

Die Vorträge finden in den Hörsälen U 113, NE 16, S 379, S 481 und im Klubraum der Chemischen Institute der Universität Bern, Freiestrasse 3, sowie im Gemeinschaftshörsaal des Physiologischen Instituts der Universität und in der Aula Muesmatt, beide Gertrud-
Dr. D. Mühlemann, Glauser Studer Stüssi AG

Was ist zu tun? Sicherheit Leben - Verantwortung übernehmen

Anmeldung und Information:

SVCT, Postfach 46, CH-4007 Basel

Telefon 061/688 4336 und 061/324 II 1 I 
European Federation for Medicinal Chemistry and the American chemical Society, Division of Medicinal Chemistry

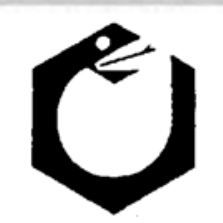

The Section of Medicinal Chemistry of the Swiss Chemical Society cordially invites you to attend the

\section{XIIth International Symposium on Medicinal Chemistry}

Basel, Switzerland, September 13-17, 1992

The European Federation for Medicinal Chemistry, comprised of representatives of national medicinal chemistry organizations in Europe, organizes biennial International Medicinal Chemistry Symposia. Previous symposia were held in Florence (1962), Münster (1968), Milan (1972), Noordwijkerhout (1974), Paris (1976), Brighton (1978), Torremolinos (1980), Toronto (1982, in cooperation with the Medicinal Chemistry Divisions of the Chemical Institute of Canada and the American Chemical Society), Uppsala (1984), Berlin/West (1986), Budapest (1988) and Jerusalem (1990).

The Symposium will be held in Basel at the European World Trade and Convention Center, starting on Sunday afternoon (September 13) with the Registration and Inaugural Lecture. The scientific programme will take place from Monday morning (September 14) until Thursday (September 17).

The official language of the Symposium will be English.

Chairman of the Organizing Committee

E. Kyburz (CH)

Chairman of the Scientific Committee

B. Testa $(\mathrm{CH})$

Scientific Programme

The programme will focus on a number of selected themes of current significance. These will be covered in one inaugural lecture, 4 plenary lectures and 36 main lectures. Special therapeutic areas as well as general methodological approaches will be presented.

Specialized themes according to mechanisms of action:

- Proteases and their inhibitors

- The immune system as a drug target

- Peptidomimetics acting on peptide receptors

- Agents affecting post-receptors events

- Selected enzyme inhibitors

- Drugs acting on neurotransmitter systems

- Drugs acting on nucleic acids and nucleic acid processing enzymes

- Ion channel modulators

General themes:

- Exciting new topics

- Approaches in lead finding and lead optimization

- Molecular toxicology

- Prodrugs and targeted drug delivery

All correspondence should be addressed to:

XIIth International Symposium on Medicinal Chemistry Administrative Secretariat

P.O. Box 141

$\mathrm{CH}-4007$ Basel

Switzerland

\section{Roussel-Preis 1992}

Angesichts der ständig wachsenden Bedeutung der Steroide für die Gesundheit der Menschen, der Tiere und vielleicht bald auch der Pflanzen war es notwendig geworden, einen internationalen Preis zur Förderung der Forschung auf diesem Gebiet zu schaffen.

Der Roussel-Preis, der 1968 auf Initiative von Herrn Prof. J. Mathieu gestiftet wurde, wird alle zwei Jahre von einem Komitee international anerkannter Spezialisten an einen oder zwei Chemiker, Biochemiker oder Physiologen für eine spezielle Leistung auf diesem Gebiet verliehen.

Die bisherigen Preisträger sind:

- 1970, Prof. W.S. Johnson für seine Arbeiten über nicht enzymatische biogeneseartige Steroidsynthesen,

- 1972, Prof. J.W. Cornforth für seine Arbeiten über die Enzyme der Cholesterolbiosynthese,

- 1974, Prof. E. Kodicek und Prof. H.F. DeLuca für ihre Arbeiten über die Metaboliten und den Aktionsmechanismus des Cholecalciferols,

- 1976, Prof. E.E. Baulieu und Prof. E.V.Jensen für ihre Arbeiten über die Hormonrezeptoren,

- 1978, Prof. R.C. Breslow' und Prof. G. Stork für ihre Chemie- und Synthese-Arbeiten auf dem Steroid-Gebiet,

- 1980, Prof. K. Arima und Prof. C. J. Sih für ihre Arbeiten über die mikrobiologische Spaltung der Seitenkette der Sterole,

- 1982, Prof. P. Benveniste und Prof. T.W. Goodw'in für ihre Arbeiten über die Biosynthese der Phytosterole,

- 1984, Prof. S. Lieberman für seine Arbeiten über Biosynthese, Biochemie und Physiologie der Steroid-Hormone,

- 1986, Dr. P. Albrecht und Prof. G. Ourisson für ihre Arbeiten über die Identifizierung und Untersuchung der Squalenoide,

- 1988, Prof. C. Djerassi für seine Arbeiten über Isolierung, Strukturbestimmung, Synthese und Biosynthese der Sterole maritimen Ursprungs,

- 1990, Prof.P.Chambon für seine Arbeiten über Klonierung und Struktur der Steroid-Hormonrezeptore.

Die nächste Preisverleihung, in Höhe von 40000 \$, wird im Herbst 1992 stattfinden. Der Preis soll einen oder mehrere Forscher für massgebende Arbeiten auf dem Gebiet der Steroide und verwandten Squalenoide auszeichnen, deren Ergebnisse vor dem 31. Dezember 1991 veröffentlicht wurden.

Die Jury für das Jahr 1992 setzt sich wie folgt zusammen:

Präsident: Sir Derek Barton

Mitglieder: Professoren M. Akhtar, J. Gorski, N. Ikekaw'a, J. Mathicu, Y. Mazur, J. Sjövall

Nationalität und Arbeitsplatz haben keinerlei Einfluss auf die Entscheidung der Kommission. Die Kandidaten müssen von einem anerkannten Wissenschaftler, der von zwei weiteren Paten unterstützt wird, auf speziellen Formularen vorgeschlagen werden.

Vorschläge müssen bis zum I. Januar 1992 dem Prïsidenten oder dem Sekretariat des Roussel-Preises eingereicht werden.

Für den Versand der Formulare und für alle weiteren Informationen ist das Sekretariat zuständig.

Sekretariat des Roussel-Preises

Institut Scientifique Roussel, 35, Boulevard des Invalides, F-75007 Paris 
European Federation for Medicinal Chemistry and the American chemical Society, Division of Medicinal Chemistry

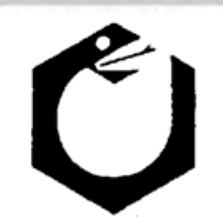

The Section of Medicinal Chemistry of the Swiss Chemical Society cordially invites you to attend the

\section{XIIth International Symposium on Medicinal Chemistry}

Basel, Switzerland, September 13-17, 1992

The European Federation for Medicinal Chemistry, comprised of representatives of national medicinal chemistry organizations in Europe, organizes biennial International Medicinal Chemistry Symposia. Previous symposia were held in Florence (1962), Münster (1968), Milan (1972), Noordwijkerhout (1974), Paris (1976), Brighton (1978), Torremolinos (1980), Toronto (1982, in cooperation with the Medicinal Chemistry Divisions of the Chemical Institute of Canada and the American Chemical Society), Uppsala (1984), Berlin/West (1986), Budapest (1988) and Jerusalem (1990).

The Symposium will be held in Basel at the European World Trade and Convention Center, starting on Sunday afternoon (September 13) with the Registration and Inaugural Lecture. The scientific programme will take place from Monday morning (September 14) until Thursday (September 17).

The official language of the Symposium will be English.

Chairman of the Organizing Committee

E. Kyburz (CH)

Chairman of the Scientific Committee

B. Testa $(\mathrm{CH})$

Scientific Programme

The programme will focus on a number of selected themes of current significance. These will be covered in one inaugural lecture, 4 plenary lectures and 36 main lectures. Special therapeutic areas as well as general methodological approaches will be presented.

Specialized themes according to mechanisms of action:

- Proteases and their inhibitors

- The immune system as a drug target

- Peptidomimetics acting on peptide receptors

- Agents affecting post-receptors events

- Selected enzyme inhibitors

- Drugs acting on neurotransmitter systems

- Drugs acting on nucleic acids and nucleic acid processing enzymes

- Ion channel modulators

General themes:

- Exciting new topics

- Approaches in lead finding and lead optimization

- Molecular toxicology

- Prodrugs and targeted drug delivery

All correspondence should be addressed to:

XIIth International Symposium on Medicinal Chemistry Administrative Secretariat

P.O. Box 141

$\mathrm{CH}-4007$ Basel

Switzerland

\section{Roussel-Preis 1992}

Angesichts der ständig wachsenden Bedeutung der Steroide für die Gesundheit der Menschen, der Tiere und vielleicht bald auch der Pflanzen war es notwendig geworden, einen internationalen Preis zur Förderung der Forschung auf diesem Gebiet zu schaffen.

Der Roussel-Preis, der 1968 auf Initiative von Herrn Prof. J. Mathieu gestiftet wurde, wird alle zwei Jahre von einem Komitee international anerkannter Spezialisten an einen oder zwei Chemiker, Biochemiker oder Physiologen für eine spezielle Leistung auf diesem Gebiet verliehen.

Die bisherigen Preisträger sind:

- 1970, Prof. W.S. Johnson für seine Arbeiten über nicht enzymatische biogeneseartige Steroidsynthesen,

- 1972, Prof. J.W. Cornforth für seine Arbeiten über die Enzyme der Cholesterolbiosynthese,

- 1974, Prof. E. Kodicek und Prof. H.F. DeLuca für ihre Arbeiten über die Metaboliten und den Aktionsmechanismus des Cholecalciferols,

- 1976, Prof. E.E. Baulieu und Prof. E.V.Jensen für ihre Arbeiten über die Hormonrezeptoren,

- 1978, Prof. R.C. Breslow' und Prof. G. Stork für ihre Chemie- und Synthese-Arbeiten auf dem Steroid-Gebiet,

- 1980, Prof. K. Arima und Prof. C. J. Sih für ihre Arbeiten über die mikrobiologische Spaltung der Seitenkette der Sterole,

- 1982, Prof. P. Benveniste und Prof. T.W. Goodw'in für ihre Arbeiten über die Biosynthese der Phytosterole,

- 1984, Prof. S. Lieberman für seine Arbeiten über Biosynthese, Biochemie und Physiologie der Steroid-Hormone,

- 1986, Dr. P. Albrecht und Prof. G. Ourisson für ihre Arbeiten über die Identifizierung und Untersuchung der Squalenoide,

- 1988, Prof. C. Djerassi für seine Arbeiten über Isolierung, Strukturbestimmung, Synthese und Biosynthese der Sterole maritimen Ursprungs,

- 1990, Prof.P.Chambon für seine Arbeiten über Klonierung und Struktur der Steroid-Hormonrezeptore.

Die nächste Preisverleihung, in Höhe von 40000 \$, wird im Herbst 1992 stattfinden. Der Preis soll einen oder mehrere Forscher für massgebende Arbeiten auf dem Gebiet der Steroide und verwandten Squalenoide auszeichnen, deren Ergebnisse vor dem 31. Dezember 1991 veröffentlicht wurden.

Die Jury für das Jahr 1992 setzt sich wie folgt zusammen:

Präsident: Sir Derek Barton

Mitglieder: Professoren M. Akhtar, J. Gorski, N. Ikekaw'a, J. Mathicu, Y. Mazur, J. Sjövall

Nationalität und Arbeitsplatz haben keinerlei Einfluss auf die Entscheidung der Kommission. Die Kandidaten müssen von einem anerkannten Wissenschaftler, der von zwei weiteren Paten unterstützt wird, auf speziellen Formularen vorgeschlagen werden.

Vorschläge müssen bis zum I. Januar 1992 dem Prïsidenten oder dem Sekretariat des Roussel-Preises eingereicht werden.

Für den Versand der Formulare und für alle weiteren Informationen ist das Sekretariat zuständig.

Sekretariat des Roussel-Preises

Institut Scientifique Roussel, 35, Boulevard des Invalides, F-75007 Paris 
CHIMIA 45 (1991) Nr. 9 (September)

Roche übernimmt PCR-Technologie von Cetus und bildet strategische Allianz mit Perkin-Elmer

In einer Reihe von Vereinbarungen erwirbt Roche alle Rechte an der bahnbrechenden Technologie der Polymerase-Kettenreaktion (PCR) von Cetus Corporation, Emeryville, Californien. Damit wird die Roche Diagnostika Division künftig über alle technischen und herstellungsorientierten Rechte sowie Patentrechte für alle bekannten sowie noch unbekannten PCR-Anwendungsgebiete verfügen. Roche entrichtet dafür einen Kaufpreis von 300 Mio. US \$ sowie umsatzabhängige Lizenzgebühren bis zu maximal 30 Mio. US \$. Das Abkommen mit Cetus bedarf noch der Zustimmung der Cetus-Aktionäre sowie der zuständigen US-Behörden.

Roche geht gleichzeitig mit der Perkin-Elmer Corporation in Norwalk, Connecticut, eine strategische Allianz ein. Einige der von Roche erworbenen PCR-Rechte werden exklusiv an die Perkin-Elmer Corporation für deren traditionelle Märkte lizenziert. In einem früheren Abkommen hatte Cetus Rechte für die Märkte in den PCR-Anwendungsgebieten Forschung, Industrie, Umweltschutz und Identitätstests in Lizenz an das Gemeinschaftsunternehmen Perkin-Elmer Cetus Instruments (PECI) vergeben, das zu $51 \%$ Perkin-Elmer und zu $49 \%$ Cetus gehört. $P E C I$ hat in den letzten fünf Jahren die PCR-Technologie erfolgreich auf verschiedenen Märkten eingeführt. Perkin-Elmer und Cetus sind übereingekommen, $\mathrm{PECI}$ aufzulösen, sobald die Vereinbarung mit Roche in Kraft tritt. Perkin-Elmer übernimmt das Geräte-Geschäft von $\mathrm{PECl}$ und schliesst ein neues Abkommen mit Roche ab, wonach Perkin-Elmer die exklusiven Rechte für den Vertrieb von PCR-Geräten und PCR-Reagenzien auf seinen traditionellen Märkten erhält. Ausserdem wird Perkin-Elmer weiterhin PCR-Geräte für diese Märkte entwickeln und herstellen.

Roche wird künftig die Geräte und Reagenzien für alle PCR-Anwendungen auf dem Gebiet der In vitro-Diagnostik in der Human- und Veterinärmedizin entwickeln, herstellen und vertreiben. Hierzu wird die Roche Diagnostika Division sämtliche PCR-Aktivitäten in einer neuen Geschäftseinheit zusammenfassen. Mit dem vollen Erwerb der PCR-Technologie unterstreicht $R o$ che die Absicht, weltweit in eine Spitzenposition auf dem Diagnostika-Sektor vorzustossen. Heute ist PCR bereits ein erprobtes diagnostisches Werkzeug, aber das volle Potential dieser Technologie zeich- net sich bei der Diagnose und $\mathrm{Be}$ handlung von Krankheiten erst in Umrissen ab.

Im Rahmen der anfangs 1989 getroffenen Vereinbarungen zwischen Roche und Cetus über eine Zusammenarbeit bei der Entwicklung und Vermarktung von diagnostischen Produkten und Serviceleistungen auf der Basis der «GeneAmp» PCRTechnologie von Cetus haben Roche Forscher begonnen, die ersten kommerziellen Anwendungen für Infektionskrankheiten wie AIDS, Lyme-Krankheit (Borreliose) und Tuberkulose zu entwickeln. Mit den neuen Vereinbarungen wird Roche auch alle Rechte an der PCR-Forschung von Cetus übernehmen, die sich auf die Gebiete der Gerichtsmedizin, der Krebsdiagnostik sowie der Erkennung von Erbkrankheiten und verschiedener anderer Infektionskrankheiten konzentriert.

Von Roche Biomedical Laboratories $(R B L)$, dem klinischen Service-Laboratoriennetz der Diagnostika Division in den USA, wird das PCR-Verfahren bereits kommerziell genutzt, so beispielsweise zum Fruihnachweis des AIDS-Virus. Im Frühjahr dieses Jahres hat Roche an SmithKline Beecham Clinical Laboratories und an MediGene, Inc. Lizenzen für den Bereich der in vitro PCR-Labortests vergeben.

Die PCR-Methode erlaubt, innerhalb weniger Stunden ein einzelnes Segment der DNA aus einem Trillionstel Gramm Erbmaterial mit Hilfe eines speziellen PolymeraseEnzyms millionenfach zu kopieren und damit eine genügende Menge für den diagnostischen Nachweis von biologischem Erbmaterial zu gewinnen, so etwa von Viren oder Krebszellen. Ferner kann die Technologie zur Bestimmung von Erbkrankheiten, zum Vaterschaftsnachweis sowie für die kriminalistische Spurensuche eingesetzt werden.

Cetus Corporation mit Sitz in Emeryville, Californien, und mit einer europäischen Niederlassung in Amsterdam, Niederlande, forscht in der modernen Biotechnologie und entwickelt vor allem neuartige immunologische Medikamente.

Die Perkin-Elmer Corporation in Norwalk, Connecticut, ist weltweit ein Marktführer auf dem Gebiet der Forschungs-, Analyse- und Überwachungs-Geräte für die Biotechnologie, die Chemie und den Umweltschutz; ausserdem werden weltweit spezielle Lacke und Überzüge für Hochtechnologiebereiche produziert und vertrieben.

\section{Bei der Redaktion eingetroffene Bücher}

L. Alberghina, R.D. Schmid, R. Verger

'Lipases: Structure, Mechanism and Genetic Engineering'

GBF Monographs Volume 16

VCH Verlagsgesellschaft mbH, Weinheim, 1991

Dechema Chemistry Data Series

published by DECHEMA, Deutsche Gesellschaft für Chemisches Apparatewesen, Chemische Technik und Biotechnologie e.V., 1991. Eds.: D. Behrens, R. Eckermann

Vol. I, Part $2 \mathrm{f}$

J. Gmehling, U. Onken, J.R. Rarey

'Vapor-Liquid Equilibrium Data Collection'

Organic Hydroxy Compounds: Alcohols and Phenols (Supplement 4)

Vol. III, Part 3

J. Gmehling, T. Holderbaum

'Heats of Mixing Data Collection'

Binary and Multicomponent Systems (Supplement 1)

Vol. III, Part 4

J. Gmehling, T. Holderbaum

'Heats of Mixing Data Collection'

Binary and Multicomponent Systems (Supplement 2)

Vol. XI

H. Engels

'Phase Equilibria and Phase Diagrams of Electrolytes'

\section{Personalia}

\section{Geburtstage}

Conrad H. Schneider

Prof. Dr. phil. nat., Hünibach, Mitglied des SChV, feiert am 4.10.91 seinen 60 . Geburtstag.

Hans Zwicky

Dr. Chem., Ersigen, Mitglied des SChV, feiert am 11.10 .91 seinen 70 Geburtstag.

Guido Ebner

Dr. phil. II, Physikochemiker, Eiken, Mitglied des SChV, feiert am 21.10 .91 seinen 60 . Geburtstag.

\section{Neue Mitglieder}

Jean-Marc Leutenegger Alpenstrasse 87, 2502 Bie

\section{Albert Lachavanne}

Chemiker, Chêne-Bougeries, Mitglied des SChV, feiert am 21.10.91 seinen 65 . Geburtstag.

Hans Wegmüller

Dr. Chem., Riehen, Mitglied des SChV, feiert am 24.10.91 seinen 60 . Geburtstag. 
CHIMIA 45 (1991) Nr. 9 (September)

Roche übernimmt PCR-Technologie von Cetus und bildet strategische Allianz mit Perkin-Elmer

In einer Reihe von Vereinbarungen erwirbt Roche alle Rechte an der bahnbrechenden Technologie der Polymerase-Kettenreaktion (PCR) von Cetus Corporation, Emeryville, Californien. Damit wird die Roche Diagnostika Division künftig über alle technischen und herstellungsorientierten Rechte sowie Patentrechte für alle bekannten sowie noch unbekannten PCR-Anwendungsgebiete verfügen. Roche entrichtet dafür einen Kaufpreis von 300 Mio. US \$ sowie umsatzabhängige Lizenzgebühren bis zu maximal 30 Mio. US \$. Das Abkommen mit Cetus bedarf noch der Zustimmung der Cetus-Aktionäre sowie der zuständigen US-Behörden.

Roche geht gleichzeitig mit der Perkin-Elmer Corporation in Norwalk, Connecticut, eine strategische Allianz ein. Einige der von Roche erworbenen PCR-Rechte werden exklusiv an die Perkin-Elmer Corporation für deren traditionelle Märkte lizenziert. In einem früheren Abkommen hatte Cetus Rechte für die Märkte in den PCR-Anwendungsgebieten Forschung, Industrie, Umweltschutz und Identitätstests in Lizenz an das Gemeinschaftsunternehmen Perkin-Elmer Cetus Instruments (PECI) vergeben, das zu $51 \%$ Perkin-Elmer und zu $49 \%$ Cetus gehört. $P E C I$ hat in den letzten fünf Jahren die PCR-Technologie erfolgreich auf verschiedenen Märkten eingeführt. Perkin-Elmer und Cetus sind übereingekommen, $\mathrm{PECI}$ aufzulösen, sobald die Vereinbarung mit Roche in Kraft tritt. Perkin-Elmer übernimmt das Geräte-Geschäft von $\mathrm{PECl}$ und schliesst ein neues Abkommen mit Roche ab, wonach Perkin-Elmer die exklusiven Rechte für den Vertrieb von PCR-Geräten und PCR-Reagenzien auf seinen traditionellen Märkten erhält. Ausserdem wird Perkin-Elmer weiterhin PCR-Geräte für diese Märkte entwickeln und herstellen.

Roche wird künftig die Geräte und Reagenzien für alle PCR-Anwendungen auf dem Gebiet der In vitro-Diagnostik in der Human- und Veterinärmedizin entwickeln, herstellen und vertreiben. Hierzu wird die Roche Diagnostika Division sämtliche PCR-Aktivitäten in einer neuen Geschäftseinheit zusammenfassen. Mit dem vollen Erwerb der PCR-Technologie unterstreicht $R o$ che die Absicht, weltweit in eine Spitzenposition auf dem Diagnostika-Sektor vorzustossen. Heute ist PCR bereits ein erprobtes diagnostisches Werkzeug, aber das volle Potential dieser Technologie zeich- net sich bei der Diagnose und $\mathrm{Be}$ handlung von Krankheiten erst in Umrissen ab.

Im Rahmen der anfangs 1989 getroffenen Vereinbarungen zwischen Roche und Cetus über eine Zusammenarbeit bei der Entwicklung und Vermarktung von diagnostischen Produkten und Serviceleistungen auf der Basis der «GeneAmp» PCRTechnologie von Cetus haben Roche Forscher begonnen, die ersten kommerziellen Anwendungen für Infektionskrankheiten wie AIDS, Lyme-Krankheit (Borreliose) und Tuberkulose zu entwickeln. Mit den neuen Vereinbarungen wird Roche auch alle Rechte an der PCR-Forschung von Cetus übernehmen, die sich auf die Gebiete der Gerichtsmedizin, der Krebsdiagnostik sowie der Erkennung von Erbkrankheiten und verschiedener anderer Infektionskrankheiten konzentriert.

Von Roche Biomedical Laboratories $(R B L)$, dem klinischen Service-Laboratoriennetz der Diagnostika Division in den USA, wird das PCR-Verfahren bereits kommerziell genutzt, so beispielsweise zum Fruihnachweis des AIDS-Virus. Im Frühjahr dieses Jahres hat Roche an SmithKline Beecham Clinical Laboratories und an MediGene, Inc. Lizenzen für den Bereich der in vitro PCR-Labortests vergeben.

Die PCR-Methode erlaubt, innerhalb weniger Stunden ein einzelnes Segment der DNA aus einem Trillionstel Gramm Erbmaterial mit Hilfe eines speziellen PolymeraseEnzyms millionenfach zu kopieren und damit eine genügende Menge für den diagnostischen Nachweis von biologischem Erbmaterial zu gewinnen, so etwa von Viren oder Krebszellen. Ferner kann die Technologie zur Bestimmung von Erbkrankheiten, zum Vaterschaftsnachweis sowie für die kriminalistische Spurensuche eingesetzt werden.

Cetus Corporation mit Sitz in Emeryville, Californien, und mit einer europäischen Niederlassung in Amsterdam, Niederlande, forscht in der modernen Biotechnologie und entwickelt vor allem neuartige immunologische Medikamente.

Die Perkin-Elmer Corporation in Norwalk, Connecticut, ist weltweit ein Marktführer auf dem Gebiet der Forschungs-, Analyse- und Überwachungs-Geräte für die Biotechnologie, die Chemie und den Umweltschutz; ausserdem werden weltweit spezielle Lacke und Überzüge für Hochtechnologiebereiche produziert und vertrieben.

\section{Bei der Redaktion eingetroffene Bücher}

L. Alberghina, R.D. Schmid, R. Verger

'Lipases: Structure, Mechanism and Genetic Engineering'

GBF Monographs Volume 16

VCH Verlagsgesellschaft mbH, Weinheim, 1991

Dechema Chemistry Data Series

published by DECHEMA, Deutsche Gesellschaft für Chemisches Apparatewesen, Chemische Technik und Biotechnologie e.V., 1991. Eds.: D. Behrens, R. Eckermann

Vol. I, Part $2 \mathrm{f}$

J. Gmehling, U. Onken, J.R. Rarey

'Vapor-Liquid Equilibrium Data Collection'

Organic Hydroxy Compounds: Alcohols and Phenols (Supplement 4)

Vol. III, Part 3

J. Gmehling, T. Holderbaum

'Heats of Mixing Data Collection'

Binary and Multicomponent Systems (Supplement 1)

Vol. III, Part 4

J. Gmehling, T. Holderbaum

'Heats of Mixing Data Collection'

Binary and Multicomponent Systems (Supplement 2)

Vol. XI

H. Engels

'Phase Equilibria and Phase Diagrams of Electrolytes'

\section{Personalia}

\section{Geburtstage}

Conrad H. Schneider

Prof. Dr. phil. nat., Hünibach, Mitglied des SChV, feiert am 4.10.91 seinen 60 . Geburtstag.

Hans Zwicky

Dr. Chem., Ersigen, Mitglied des SChV, feiert am 11.10 .91 seinen 70 Geburtstag.

Guido Ebner

Dr. phil. II, Physikochemiker, Eiken, Mitglied des SChV, feiert am 21.10 .91 seinen 60 . Geburtstag.

\section{Neue Mitglieder}

Jean-Marc Leutenegger Alpenstrasse 87, 2502 Bie

\section{Albert Lachavanne}

Chemiker, Chêne-Bougeries, Mitglied des SChV, feiert am 21.10.91 seinen 65 . Geburtstag.

Hans Wegmüller

Dr. Chem., Riehen, Mitglied des SChV, feiert am 24.10.91 seinen 60 . Geburtstag. 
CHIMIA 45 (1991) Nr. 9 (September)

Roche übernimmt PCR-Technologie von Cetus und bildet strategische Allianz mit Perkin-Elmer

In einer Reihe von Vereinbarungen erwirbt Roche alle Rechte an der bahnbrechenden Technologie der Polymerase-Kettenreaktion (PCR) von Cetus Corporation, Emeryville, Californien. Damit wird die Roche Diagnostika Division künftig über alle technischen und herstellungsorientierten Rechte sowie Patentrechte für alle bekannten sowie noch unbekannten PCR-Anwendungsgebiete verfügen. Roche entrichtet dafür einen Kaufpreis von 300 Mio. US \$ sowie umsatzabhängige Lizenzgebühren bis zu maximal 30 Mio. US \$. Das Abkommen mit Cetus bedarf noch der Zustimmung der Cetus-Aktionäre sowie der zuständigen US-Behörden.

Roche geht gleichzeitig mit der Perkin-Elmer Corporation in Norwalk, Connecticut, eine strategische Allianz ein. Einige der von Roche erworbenen PCR-Rechte werden exklusiv an die Perkin-Elmer Corporation für deren traditionelle Märkte lizenziert. In einem früheren Abkommen hatte Cetus Rechte für die Märkte in den PCR-Anwendungsgebieten Forschung, Industrie, Umweltschutz und Identitätstests in Lizenz an das Gemeinschaftsunternehmen Perkin-Elmer Cetus Instruments (PECI) vergeben, das zu $51 \%$ Perkin-Elmer und zu $49 \%$ Cetus gehört. $P E C I$ hat in den letzten fünf Jahren die PCR-Technologie erfolgreich auf verschiedenen Märkten eingeführt. Perkin-Elmer und Cetus sind übereingekommen, $\mathrm{PECI}$ aufzulösen, sobald die Vereinbarung mit Roche in Kraft tritt. Perkin-Elmer übernimmt das Geräte-Geschäft von $\mathrm{PECl}$ und schliesst ein neues Abkommen mit Roche ab, wonach Perkin-Elmer die exklusiven Rechte für den Vertrieb von PCR-Geräten und PCR-Reagenzien auf seinen traditionellen Märkten erhält. Ausserdem wird Perkin-Elmer weiterhin PCR-Geräte für diese Märkte entwickeln und herstellen.

Roche wird künftig die Geräte und Reagenzien für alle PCR-Anwendungen auf dem Gebiet der In vitro-Diagnostik in der Human- und Veterinärmedizin entwickeln, herstellen und vertreiben. Hierzu wird die Roche Diagnostika Division sämtliche PCR-Aktivitäten in einer neuen Geschäftseinheit zusammenfassen. Mit dem vollen Erwerb der PCR-Technologie unterstreicht $R o$ che die Absicht, weltweit in eine Spitzenposition auf dem Diagnostika-Sektor vorzustossen. Heute ist PCR bereits ein erprobtes diagnostisches Werkzeug, aber das volle Potential dieser Technologie zeich- net sich bei der Diagnose und $\mathrm{Be}$ handlung von Krankheiten erst in Umrissen ab.

Im Rahmen der anfangs 1989 getroffenen Vereinbarungen zwischen Roche und Cetus über eine Zusammenarbeit bei der Entwicklung und Vermarktung von diagnostischen Produkten und Serviceleistungen auf der Basis der «GeneAmp» PCRTechnologie von Cetus haben Roche Forscher begonnen, die ersten kommerziellen Anwendungen für Infektionskrankheiten wie AIDS, Lyme-Krankheit (Borreliose) und Tuberkulose zu entwickeln. Mit den neuen Vereinbarungen wird Roche auch alle Rechte an der PCR-Forschung von Cetus übernehmen, die sich auf die Gebiete der Gerichtsmedizin, der Krebsdiagnostik sowie der Erkennung von Erbkrankheiten und verschiedener anderer Infektionskrankheiten konzentriert.

Von Roche Biomedical Laboratories $(R B L)$, dem klinischen Service-Laboratoriennetz der Diagnostika Division in den USA, wird das PCR-Verfahren bereits kommerziell genutzt, so beispielsweise zum Fruihnachweis des AIDS-Virus. Im Frühjahr dieses Jahres hat Roche an SmithKline Beecham Clinical Laboratories und an MediGene, Inc. Lizenzen für den Bereich der in vitro PCR-Labortests vergeben.

Die PCR-Methode erlaubt, innerhalb weniger Stunden ein einzelnes Segment der DNA aus einem Trillionstel Gramm Erbmaterial mit Hilfe eines speziellen PolymeraseEnzyms millionenfach zu kopieren und damit eine genügende Menge für den diagnostischen Nachweis von biologischem Erbmaterial zu gewinnen, so etwa von Viren oder Krebszellen. Ferner kann die Technologie zur Bestimmung von Erbkrankheiten, zum Vaterschaftsnachweis sowie für die kriminalistische Spurensuche eingesetzt werden.

Cetus Corporation mit Sitz in Emeryville, Californien, und mit einer europäischen Niederlassung in Amsterdam, Niederlande, forscht in der modernen Biotechnologie und entwickelt vor allem neuartige immunologische Medikamente.

Die Perkin-Elmer Corporation in Norwalk, Connecticut, ist weltweit ein Marktführer auf dem Gebiet der Forschungs-, Analyse- und Überwachungs-Geräte für die Biotechnologie, die Chemie und den Umweltschutz; ausserdem werden weltweit spezielle Lacke und Überzüge für Hochtechnologiebereiche produziert und vertrieben.

\section{Bei der Redaktion eingetroffene Bücher}

L. Alberghina, R.D. Schmid, R. Verger

'Lipases: Structure, Mechanism and Genetic Engineering'

GBF Monographs Volume 16

VCH Verlagsgesellschaft mbH, Weinheim, 1991

Dechema Chemistry Data Series

published by DECHEMA, Deutsche Gesellschaft für Chemisches Apparatewesen, Chemische Technik und Biotechnologie e.V., 1991. Eds.: D. Behrens, R. Eckermann

Vol. I, Part $2 \mathrm{f}$

J. Gmehling, U. Onken, J.R. Rarey

'Vapor-Liquid Equilibrium Data Collection'

Organic Hydroxy Compounds: Alcohols and Phenols (Supplement 4)

Vol. III, Part 3

J. Gmehling, T. Holderbaum

'Heats of Mixing Data Collection'

Binary and Multicomponent Systems (Supplement 1)

Vol. III, Part 4

J. Gmehling, T. Holderbaum

'Heats of Mixing Data Collection'

Binary and Multicomponent Systems (Supplement 2)

Vol. XI

H. Engels

'Phase Equilibria and Phase Diagrams of Electrolytes'

\section{Personalia}

\section{Geburtstage}

Conrad H. Schneider

Prof. Dr. phil. nat., Hünibach, Mitglied des SChV, feiert am 4.10.91 seinen 60 . Geburtstag.

Hans Zwicky

Dr. Chem., Ersigen, Mitglied des SChV, feiert am 11.10 .91 seinen 70 Geburtstag.

Guido Ebner

Dr. phil. II, Physikochemiker, Eiken, Mitglied des SChV, feiert am 21.10 .91 seinen 60 . Geburtstag.

\section{Neue Mitglieder}

Jean-Marc Leutenegger Alpenstrasse 87, 2502 Bie

\section{Albert Lachavanne}

Chemiker, Chêne-Bougeries, Mitglied des SChV, feiert am 21.10.91 seinen 65 . Geburtstag.

Hans Wegmüller

Dr. Chem., Riehen, Mitglied des SChV, feiert am 24.10.91 seinen 60 . Geburtstag. 